\title{
PENERAPAN MODEL PEMBELAJARANPROBLEM BASED LEARNING UNTUK MENINGKATKAN HASIL BELAJAR KONSEP ALAT KOMUNIKASI PELAJARAN PRAKARYA DAN KEWIRAUSAHAAN
}

\author{
W. Pradnyadinata 1 , I P Suka Arsa², A. Adiarta ${ }^{3}$ \\ 1,2,3Prodi Pendidikan Teknik Elektro, Universitas Pendidikan Ganesha, Singaraja \\ e-mail: gamaradiasi@gmail.com, suka.arsa@undiksha.ac.id,agus.adiarta@undiksha.ac.id
}

\begin{abstract}
Abstrak
Penelitian ini bertujuan untuk mendeskripsikan kemampuan peserta didik dalam melakukan pemecahan masalah, meningkatkan kemampuan berpikir kritis yang mampu meningkatkan hasil belajar menjadi lebih baik. Pada model pembelajaran yang berbasis masalah yang dilakukan oleh peserta didik kelas X MIPA 1 di SMA N 4 Singaraja sebanyak 35 orang. Penelitian ini adalah sebuah penelitian tindakan kelas (PTK), dengan metode pendekatan kualitatif deskriptif, yang merujuk dari model penelitian Kemmis dan Mc Taggart yang dilakukan dalam dua siklus. Dengan langkah-langkah pelaksanaanya, seperti; 1) Perencanaan tindakan, 2) Pelaksanaan Tindakan dan Observasi, 3) Refleksi. Hasil berikut merefleksikan bahwa penerapan dari model pembelajaran problem based learning (PBL) dapat meningkatkan hasil belajar pada ranah kognitif. Rata-rata hasil belajarmata pelajaran prakarya dan kewirausahaan konsep alat komunikasi dalam siklus I dan siklus II meningkat dari 70,94 menjadi 82,77 yang dikategorikan tinggi dari tingkat penguasaan materi $(82,77 \%)$. Jumlah peserta didik yang berada di atas kriteria ketuntasan minimal juga meningkat menjadi $88,57 \%$ pada siklus II daripada ketuntasan minimal pada siklus I sebanyak $40 \%$. Hasil belajar mata prakarya dan kewirausahaan pada pengajaran konsep alat komunikasi telah mengalami peningkatan secara signifikan. Disisi lain, model pembelajaran problem based learning (PBL) terbukti cukup efektif digunakan pada konsep alat komunikasi.
\end{abstract}

Kata kunci: Problem based learning, Hasil belajar

\begin{abstract}
This study aimed to describe the quality of student's abilities in problem solving, improving critical thinking to get learning outcome much better. In the model of learning that use problem based learning operating the learning of process of student's grade $X$ (science department-one) 4 singaraja of senior high school about 35 people. This research is a classroom action research (CAR), with using a descriptif of qualitative research method, which refers to the the model of Kemmis and Mc Taggart who performed a total of two cycles. Each cycle consist of four stages, namely: 1) Action Plan, 2) Taking Action and Observation Action, 3) Reflection. The result of this study indicate that the application of problem-based learning model can improve learning outcomes of craft dan enterpreneurship subject's on the concept of communication device. The mean result of study of student's in the first cycle and second cycle are respectively 70,94 and 82,77 which include the high category. The number of learners who have reached values above criteria minimal of completeness also increased to $88,57 \%$ on the second cycle rather than in the first cycle as much as $40 \%$. This shows that the results of subject craft and enterpreneurship in the concept of communication device lesson has increased significantly compared to the cycle I. Besides the problem based learning model proved effective enough to be applied in the commucication device concept
\end{abstract}

Keywords: Problem Based Learning, Learning Outcomes

\section{Pendahuluan}

Kurikulum 2013 yang lahir dari pemikiran ke depan mengisyaratkan perubahan. Salah satunya, adalah di mana peserta didik diajak untuk mencari tahu bukan diberitahu dan peran sang pendidik adalah sebagai tutor. Hal itu tertuang pada UU Sisdiknas No. 20 Tahun 2003 mengatakan bahwa "Pendidikan adalah usaha sadar dan terencana untuk mewujudkan suasana belajar dan proses pembelajaran agar peserta didik secara aktif mengembangkan potensi dirinya untuk memiliki kekuatan spiritual keagamaan, pengendalian diri, kepribadian, kecerdasan, akhlak mulia, serta keterampilan yang diperlukan dirinya dan masyarakat." Diselenggarakannya, Pendidikan di sekolah menengah atas (SMA) sesuai yang tercantum pada ayat 2 adalah untuk 
meningkatkan apa yang sudah dicapai pada pendidikan dasar yakni, SD dan SMP. Diantaranya, 1) Kecerdasan,2) Pengetahu-an, 3) Kepribadian, 4) Akhlak mulia, 5) Keterampilan untuk hidup mandiri, 6) Mengikuti pendidikan lebih lanjut. Pendidikan lebih lanjut dimaksudkan yang lebih tinggi pada universitas sebagai mahasiswa setelah lulus dari sekolah menengah atas.

Untuk mencapai peningkatan tersebut, maka kemampuan diri baik dari cara berpikir ataupun keterampilan perlu ditingkatkan di mana ada empat tahap perkembangan kognitif yang dilalui terlebih dahulu bagi setiap peserta didik. Pada tahap keempat merupakan tahap operasional formal dimana remaja dapat menggunakan operasi-operasi konkritnya, untuk memben-tuk operasi yang lebih kompleks. Kemajuan pada anak selama periode ini ialah ia tidak perlu berpikir dengan pertolongan benda atau peristiwa konkrit, ia mempunyai kemampuan untuk berpikir abstrak dan anak sudah mampu memahami bentuk argumen (Piaget dalam Matt Jarvis, 2011). Anak telah mampu berpikir ilmiah mulai merumuskan masalah, membatasi masalah, menyusun hipotesis, mengumpul-kan dan mengolah data sampai dengan menarik kesimpulankesimpulan.

Dalam proses pembelajaran, dibutuhkan model pembelajaran yang inovatif ialah yang memberikan kesempatan bagi anak juga dikenal peserta didik melaksanakan sebuah kegiatan ilmiah. Tujuannya, memperluas pengertian di dalam dirinya, dan yang lebih komplek serta menghubungkannya, untuk mengembang-kan potensi di dalam diri mereka (Kartono, 1996). Berdasarkan hasil wawancara, dengan guru mata pelajaran Prakarya dan Kewirausahaan di SMA Negeri 4 Singaraja tahun ajaran 2017/2018 diketahui bahwa saat proses pembelajaran prakarya dan kewirausahaan semester ganjil kelas X MIPA 1 dipilih dan digunakan model pembelajaran demonstrasi bagi peserta didik guna mempelajari pokok bahasan alat komunikasi. Hasil belajar peserta didik pada ranah kognitif untuk materi alat komunikasi ditunjukkan pada

tabel berikut:

Tabel 1. Hasil belajar awal peserta didik kelas X MIPA 1

\begin{tabular}{ccccc}
\hline No & $\begin{array}{c}\text { Variabel } \\
\text { Terukur }\end{array}$ & $\begin{array}{c}\text { Jumlah } \\
\text { Peserta didik }\end{array}$ & Tuntas & Presentase \\
\hline 1 & Hasil Belajar & 35 Orang & 8 Orang & $\begin{array}{c}\text { Ketuntasan Klasikal } \\
\text { Kelas sebesar } 22,86 \%\end{array}$ \\
\hline
\end{tabular}

Data hasil belajar tes awal di atas, menunjukkan hasil yang jauh dari harapan pencapaian ketuntasan belajar. Jumlah peserta didik yang dikategorikan tuntas hanya sebanyak 8 orang dan mendapatkan presentase kriteria ketuntasan minimal hanya $22,86 \%$. Jelas data tersebut menggambarkan bagaimana hasil belajar peserta didik pada materi alat komunikasi secara ratarata ketuntasan klasikal belum mencapai $75 \%$.

Dalam sesi wawancara, guru memilih model pembelajaran demonstrasi karena sesuai kurikulum yang terbaru, dengan pendekatan saintifik bertujuan agar peserta didik memiliki minat mengikuti proses pembelajaran dan memperkenalkan situasi belajar dalam kelompok. Namun, la juga mengakui bahwa terdapat kelemahan dalam pelaksanaan pembelajaran menggunakan metode di atas sebab realitasnya, "jika dalam bekerja kelompok metode ini tidak efektif digunakan" la menegaskan. Pada saat itu diketahui hanya beberapa peserta didik saja yang aktif, yaitu sebanyak 10 dari 35 orang dan sisanya, yaitu 25 orang atau $71,43 \%$ dikategorikan kurang aktif. Peserta didik juga mengalami kesulitan dalam menghadapi proses pembelajaran, pengetahuan dan pemahaman mereka masih rendah mengenai materi yang diberikan khususnya, komponen elektronika yang merupakan kompetensi dasar yang wajib dikuasai. Observasi aktivitas belajar menemukan kurangnya, pengalaman yang mendukung dan mengembangkan kegiatan ilmiah dalam perkembangan kognitif mereka.Dan kegiatan belajar yang dilakukan semakin jauh dari karakteristik mereka untuk mengasah kemampuan kognitifnya dalam melakukan kegiatan penyelidikan atau penelitian.

Mempelajari prakarya dan kewirausahaan peserta didik dituntut untuk dapat mengolah sumber daya lokal agar menghasilkan sesuatu yang bernilai ekonomis berupa alat komunikasi 
yang menggunakan sumber arus DC (Kelas X). Sebelum peserta didik dapat memanfaatkan sumber daya tersebut, maka pengetahuan dan pemahaman terhadap alat dan bahan untuk mengolahnya, mutlak diperlukan, seperti dalam pembuatan rangkaian amplifier agar berfungsi sebagai alat komunikasi pengeras suara adalah memiliki suara yang jernih, maka peserta didik perlu memahami dan memperhitungkan dalam memilih komponen elektronika yang tepat," Guru prakewi menambahkan. Dengan metode yang ada peserta didik belum dapat mencapai hal tersebut serta memenuhi standar kompetensi mata pelajaran prakarya dan kewirausahaan.

Salah satu model pembelajaran yang memiliki langkah-langkah proses pembelaja-ran yakni tujuan utamanya, melatih kemampuan berpikir khususnya, secara ilmiah adalah model pembelajaran problem based learning (PBL) karena dapat memfasilitasi dan melatih keterampilan berpikir peserta didik yang nanti akan dapat mengembangkan kecerdasan, pengetahu-an, keterampilan untuk hidup madiri, dan melanjutkan pendidikannya. Menurut Tan Onn Seng "PBL merupakan pembelajaran yang menggunakan berbagai kemampuan berpikir dari peserta didik secara individu maupun kelompok untuk mengatasi permasalahan nyata sehingga pembelajaran menjadi bermakna, relevan, dan kontekstual". Di mana sebuah "tantangan" melakukan penyelidikan menjadi bahan bakar dalam proses pembelajaran.

Kurikulum terbaru 2013 atau sering disebut K-13 juga memilih model pembelajaran problem based learning (PBL) sebagai ujung tombak proses pembelajaran yang perlu diterapkan di kelas, dilandasi pendekatan ilmiah di mana proses pembelajaran selalu diawali, dengan merumuskan masalah yang diungkapkan melalui proses menanya (Rahmat, 2016). Oleh karena itu, kebutuhan guru yang paling esensial dalam melaksanakan K-13 adalah mampu membantu peserta didik merumuskan dan memecahkan masalah.

Menurut Barrows (1986) yang dikutip oleh Bilgin dkk (2008) "tujuan utama PBL menjadikan peserta didik menjadi aktif, bebas, dan belajar mandiri daripada pasif menerima pelajaran yang disampaikan kepadanya". Adapun manfaat yang dapat diberikan melalui PBL, "(1) mengembangkan keterampilan berpikir, pemecahan masalah dan intelektual; (2) belajar peranperan orang dewasa, dengan menghayati peran-peran itu melalui situasi-situasi nyata atau yang disimulasikan dan; (3) menjadi mandiri, maupun siswa otonom" (Ibrahim dan Nur, 2000; 7).

Dalam setiap pembelajaran, maka peserta didik perlu menyesuaikan dirinya, jika mereka tidak memiliki pengalaman dalam melakukan eksperimen, maka bimbingan yang lebih perlu diberikan dan direncanakan. Seperti faktor-faktor apa yang dapat mempengaruhi nilai arus listrik pada rangkaian amplifier. Hipotesis untuk masalah itu perlu diantisipasi sebelumnya, seperti nilai tegangan dan nilai tahanan. Untuk menyelidiki hipotesis yang pertama, perlu memikirkan sumber arus yang memiliki karakteristik, dengan nilai tegangan yang tidak terlalu besar dan stabil untuk memasok energi, seperti sumber arus listrik DC dari laptop, aki (terbaik), dan baterai. Untuk memeriksa yang kedua, disiapkan nilai tahanan yang sesuai, dengan berbagai macam nilai tahanan yang ada, maka nilai ini perlu dicari sebelumnya. Proses pembelajaran membentuk sikap pemecahan masalah, berpikir, bekerja kelompok, komunikasi, dan informasi berkembang secara positif (Yuan dkk, 2008). Dalam komunikasi adalah bertukar pikiran, menganalisis masalah menggunakan berbagai cara, dan memikirkan kemungkinan-kemungkinan yang terjadi.

Untuk mengetahui bagaimana model pembelajaran yang diusulkan dapat meningkatkan hasil belajar , maka diadakan penelitian yang berjudul "Penerapan Model Pembelajaran Problem Based Learning (PBL) Untuk Meningkatkan Hasil Belajar Konsep Alat Komunikasi Pada Mata Pelajaran Prakarya dan Kewirausahaan"

\section{Metode}

Model penelitian yang diterapkan pada penelitian ini adalah Penelitian Tindakan Kelas (PTK) yang memiliki tujuan utama adalah peningkatan praktek mengajar di kelas dan peningkatan situasi tempat praktik berlangsung. Menggunakan model PTK Kemmis \& Mc. Teggart yang dalam alur penelitiannya, yaitu meliputi langkah-langkah sebagai berikut;1) Perencanaan (Plan), 2) Melaksanakan tindakan (Act), 3) Melaksanakan pengamatan (Observer), 4) Mengadakan refleksi/analisis (reflection).

Model Kemmis \& Teggart merupakan pengembangan dan konsep dasar yang diperkenalkan oleh Kurt Lewis, hanya saja komponen action (tindakan), dengan 
Observe(pengamatan) dijadikan sebagai satu kesatuan disatukannya, kedua komponen tersebut disebabkan oleh adanya kenyataan bahwa penerapan antara action dan observe merupakan kegiatan yang tidak terpisahkan maksudnya, kedua kegiatan haruslah dilakukan dalam satu kesatuan waktu. Jadi, jika berlangsungnya, suatu tindakan begitu pula observasi juga dilakukan.Untuk lebih jelasnya, dapat dilihat pada siklus penelitian tindakan model Kemmis \& Mc. Teggart pada Gambar 1.

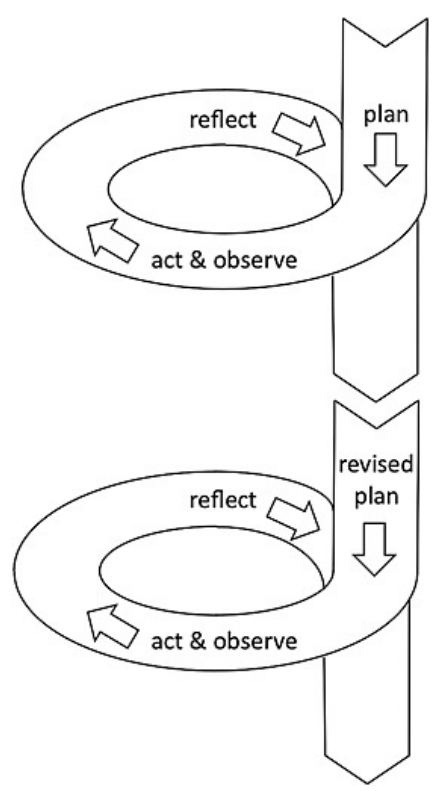

Gambar 1. Siklus Penelitian Tindakan Kelas

Diadopsi dari model Kemmis \& Mc. Teggart (2000)

Pendekatan dalam penelitian ini adalah kualitatif, karena permasalahan diteliti dari melihat dan mengamati terjadinya, perubahan dalam tindakan subjek untuk peningkatan hasil belajar mata pelajaran prakarya dan kewirausahaan. Menurut Sutopo (2002: 137) penelitian kualitatif deskriptif bertujuan untuk mengungkapkan berbagai informasi kualitatif, dengan pendeskripsian yang diteliti dan penuh nuansa untuk menggambarkan secara cermat sifat-sifat suatu hal, keadaan, fenomena, dan tidak terbatas pada pengumpulan data melainkan meliputi analisis interpretasi data.

Penelitian kualitatif deskriptif adalah penelitian di mana data yang dianalisis dan hasil analisisnya, berbentuk deskripsi fenomena, tidak berupa angka-angka atau koefesien tentang hubungan antar variabel (Aminudin, 1990:16). Maka yang lebih sederhananya, pengertian dari penelitian kualitatif, seperti yang dikemukakan oleh Laksman adalah dirancang untuk memberikan pengalaman senyatanya, dan menangkap makna sebagaimana yang tercipta di lapangan penelitian melalui interaksi langsung antara peneliti dan yang diteliti (Putu Laksman Pendit, 2003: 195).Penelitian kualitatif merupakan jenis penelitian di mana hasil penelitiannya, adalah merupakan sebuah penalaran dan persepsi yang didukung, dengan adanya bukti otentik dari kegiatan penelitian dan didukung, dengan pendapat para ahli. Menurut teori yang berkembang mengenai penelitian kualitatif, data yang dikumpulkan mencakup data primer dan data skunder demi kualitas penelitiannya.

Langkah-langkah penelitian kualitatif dari Sulistyo (Sulistyo-Basuki, 2006: 81) adalah sebagai berikut:1)Mempertimbang-kan fokus dan memilih topik, menyatakan masalah dan merumuskan pendahuluan pernyataan, 2) Mencari lokasi/ subjek potensial, memilih lokasi/ subjek yang dianggap cocok, menguji kecocokan lokasi/ subjek luas, eksplorasi, mengembangkan rencana umum, melakukan kajian percobaan/ mengumpulkan data awal, merevisi rencana umum, 3) Memusatkandiri pada himpunan aktivitas yang terfokus; mengumpulkan data, menyempurnakan rencana penelitian/ penjelasan fokus, aktivitas terfokus, 
menyempitkan pengumpulan data, analisis data, menulis temuan, seperti hasil wawancara dan observasi. Teknik pengumpulan data yang dilakukan dalam penelitian ini ada 3 (tiga), yaitu hasil test dan observasi (data primer), dan wawancara (data skunder).

Tabel 2. Teknik Pengumpulan Data

\begin{tabular}{ccccc}
\hline Data & Metode & Instrumen & Sumber & Sifat Data \\
\hline $\begin{array}{c}\text { Hasil belajar prakarya dan } \\
\text { kewirausahaan peserta } \\
\text { didik kelas X MIPA 1 }\end{array}$ & Tes & $\begin{array}{c}\text { Perangkat tes } \\
\text { (Pilihan ganda) }\end{array}$ & $\begin{array}{c}\text { Peserta } \\
\text { didik }\end{array}$ & $\begin{array}{c}\text { Interval } \\
\text { (Skor) }\end{array}$ \\
\hline
\end{tabular}

Skor hasil tes peserta didik dalam mengerjakan soal-soal meliputi skor hasil tes pengetahuan yang didapat sebelum tindakan melalui pretest, dan skor hasil tes pada setiap akhir tindakan melalui postest. Hasil dari setiap tes atau pekerjaan peserta didik digunakan untuk melihat sejauh mana perkembangan kemampuan peserta didik.Adapun kriteria penilaian hasil tes adalah sebagai berikut:

Tabel 3. Kriteria Penilaian hasil belajar

\begin{tabular}{ccccc}
\hline Huruf & $\begin{array}{c}\text { Angka } \\
0-4\end{array}$ & $\begin{array}{c}\text { Angka } \\
0-100\end{array}$ & $\begin{array}{c}\text { Angka } \\
0-10\end{array}$ & Predikat \\
\hline A & 4 & $90-100$ & $9,0-10$ & Sangat Baik \\
B & 3 & $80-89$ & $8,0-8,9$ & Baik \\
C & 2 & $65-79$ & $6,5-7,9$ & Cukup \\
D & 1 & $55-64$ & $5,5-6,4$ & Kurang \\
E & 0 & $\leq 54$ & $\leq 5,4$ & Sangat Kurang \\
\hline
\end{tabular}

Untuk menghitung hasil tes, baik pretest maupun postest pada soal tes yang dibuat, digunakan rumus percentages correction sebagai berikut ini (Ngalim Purwanto,2004: 112):

$$
\mathrm{N}=\frac{\sum \text { Skor }}{\text { Skor maksimal }} \times 100
$$

Teknik analisis data yang dilakukan sebagaimana yang disebutkan oleh Miles dan Huberman (Sugiyono, 2009: 91) mencakup reduksi data, penyajian data, dan kesimpulan atau verifikasi; 1) Reduksi Databerarti merangkum, memilih hal-hal yang pokok, memfokuskan pada hal-hal yang penting, dicari tema dan polanya" (Sugiyono, 2009: 92). Jadi data yang diperoleh agar dapat bermakna dan lebih mudah untuk disajikan perlu adanya reduksi data, 2) Penyajian Data(Data Display)“Dalam penelitian kualitatif, penyajian data bisa dilakukan dalam bentuk uraian singkat, bagan, hubungan antar kategori, flowchart dan sejenisnya" (Sugiyono, 2009: 95).Jadi penyajian data yang informatif dan jelas dalam bentuk teks naratif didukung bagan, grafik, dan tabel akan memudahkan untuk memahami apa yang terjadi serta merencanakan kerja selanjutnya, 3) Kesimpulan (Conclusion Drawing)Pernyataan singkat yang menghampiri paling akhir bertujuan untuk memberi hasil dari penelitian yang telah dilaksanakan. Proses pengambilan intisari dalam bentuk pernyataan kalimat atau formula yang singkat dan padat tetapi mengandung pengertian yang luas (Tatag, 2008).

Kesimpulan dalam penelitian ini akan menjadi temuan baru. Temuan yang berupa deskripsi/ gambaran suatu objek yang masih belum jelas, sehingga setelah diteliti menjadi jelas. Data hasil analisis perlu ditarik kesimpulannya, agar mengetahui apakah tujuan pembelajaran sudah tercapai atau belum. Jika belum, maka dilakukan tindakan selanjutnya. Dalam beberapa kondisi tindakan akan dihentikan jika masih belum berhasil (minimal pada tindakan ke 2). Dalam mengetahui tingkat keberhasilan tindakan didasarkan pada tabel tingkat penguasaan menurut 
Ngalim Purwanto sebagai berikut, (Ngalim purwanto: 103).

Tabel 4. Kriteria Tingkat Penguasaan Tingkat Penguasaan Predikat

\begin{tabular}{cc}
\hline $\begin{array}{c}\text { Tingkat } \\
\text { Penguasaan }\end{array}$ & Predikat \\
\hline $86-100 \%$ & Sangat Baik \\
$76-85 \%$ & Baik \\
$60-75 \%$ & Cukup \\
$55-59 \%$ & Kurang \\
$\leq 54 \%$ & Sangat Kurang \\
\hline
\end{tabular}

Dihitung presentase keberhasilan tindakan didasarkan pada skor yang diperoleh dari data hasil observasi. Untuk menghitung data observasi digunakan rumus sebagai berikut.

$$
\text { Observasi }=\frac{\sum \text { Skor }}{\text { Skor maksimal }} \times 100 \%
$$

Penelitian ini memiliki indikator keberhasilan sesuai hasil pengukuran nilai postest peserta didik yakni, secara individu telah mencapai sama, dengan atau melebihi $(K K M \geq 75)$ berdasarkan patokan sekolah. Dan secara klasikan rata-rata ketuntasan belajar telah melebihi $75 \%$. Kurang dari kriteria tersebut dinyatakan belum berhasil (Nana Sujana, 2005: 8).

$$
\text { Ketuntasan }=\frac{\sum \text { Skor } \geq \text { KKM }}{\sum \text { Peserta didik }} \times 100 \%
$$

Berdasarkan kriteria di atas sehingga indikator keberhasilan tindakan pada penelitian ini adalah juga meningkatnya, skor hasil belajar yang dicapai peserta didik. Tingkat keberhasilan hasil belajar peserta didik didasarkan pada perolehan nilai yang lebih tinggi dari rata-rata nilai siklus atau tes formatif sebelumnya.

\section{Hasil dan Pembahasan}

Berdasarkan refleksi awal, tingkat penguasaan materi peserta didik masih dikategorikan sedang. Sedangkan ketuntasan belajarnya, tidak mencapai kriteria ketuntasan minimal yang ditetapkan sekolah, yaitu $\geq 75$. Hasil belajar yang dinilai pada penelitian ini meliputi rata-rata hasil belajar pada ranah kognitif dan ketuntasan klasikal. Setelah diterapkan model pembelajaran problem based learning. Pada siklus I rata-rata hasil belajar yang diraih sebesar 70,94 ditingkat penguasaan materi dikategorikan sedang, dan dengan ketuntasan klasikal $40 \%$, yaitu sebanyak 14 orang dikategorikan tuntas belajar. Di sisi lain, aktivitas belajar masih dikatakan cukup direntang $61,25 \%$.

Walaupun harapan pada hasil siklus I belum tercapai, namun pembelajaran sudah dapat dilaksanakan sesuai, dengan strategi pembelajaran. Hal ini disebabkan oleh adanya, kendala yang mengganggu kegiatan pembelajaran pada siklus I. Kendala-kendala pada siklus I meliputi; 1) Peserta didik belum mengetahui cara yang benar bagaimana langkah-langkah dalam melakukan kegiatan pengukuran. 2) Peserta didik mengalami kesulitan dalam menggunakan alat ukur. 3) Ketersediaan alat belum terpenuhi secara maksimal mengingat jumlah kelompok tidak sebanding, dengan ketersediaan alat ukur.4)Motivasi peserta didik selama melakukan kegiatan pengukuran masih kurang.

Berdasarkan uraian di atas, untuk mencari pemecahannya, dilakukan diskusi bersama guru kolabolator dan memperoleh solusi terbaik untuk penerapan model pembelajaran yang lebih baik pada siklus II dan hasil belajar pun diharapkan akan lebih meningkat. Berikut ini, beberapa solusi terbaik yang bisa diterapkan, yaitu sebagai berikut; 1) Memberikan deskripsi langkahlangkah dalam melakukan kegiatan pengukuran. 2) Memberikan deskripsi cara menggunakan Jurnal Pendidikan Teknik Elektro Undiksha $\mid 76$ 
alak ukur AVO meter. 3) Membeli alat ukur atau meminjamnya, pada bagian laboratorium teknik elektro atau dari peserta didik. 4) Memberi kesempatan kepada mereka yang kurang aktif untuk dapat menunjukkan kemampuan dirinya, dan bimbingan personal maupun memberitahukan mereka pentingnya, berkolaborasi antar anggota kelompok dan memberikan yang terbaik tanpa balasan apapun.

Tabel 5. Rekapitulasi Hasil Belajar Kelas X MIPA 1 Tahun Ajaran 2017/2018

\begin{tabular}{lcccl}
\hline & \multicolumn{3}{c}{ Nilai } & \multirow{2}{*}{ Keterangan* $^{*}$} \\
\cline { 2 - 4 } & Pretest & Postestl & Postest/l & \\
Jumlah & 2364 & 2483 & 2897 & \\
Rata-rata & 67,54 & 70,94 & 82,77 & Meningkat \\
N $\geq$ KKM & 8 & 14 & 31 & \\
Ketuntasan belajar (\%) & 22,86 & 40 & 88,57 & \\
Banyak peserta & 35 & 35 & 35 & \\
\hline
\end{tabular}

Berdasarkan beberapa perbaikan pembelajaran di atas sehingga peneliti melakukan perbaikan terhadap proses pembelajaran ke siklus II, dengan merefleksi kekurangan yang ada pada siklus I sehingga hasil belajar pada siklus II pun meningkat. Pada siklus II Ketuntasan Klasikal dicapai oleh peserta didik 31 orangyang tuntas, dengan nilai rata-rata 82,77. Tingkat penguasaan materi peserta didik pun meningkat yang dikategorikan tinggi.Di sisi lain, aktivitas belajar sudah dikatakan tinggi direntang $88,75 \%$. Peningkatan pada ketuntasan klasikal sebesar $47,71 \%$ dilihat pada siklus I dan pada siklus II mencapai 88,57 \%. Berdasarkan kriteria keberhasilan tersebut, maka ketuntasan belajar peserta didik pada siklus II memenuhi target, yaitu sebanyak $88,57 \%$ atau 31 orang memperoleh nilai 75 ke atas, maka penelitian ini sudah mencapai indikator keberhasilan. Untuk lebih jelasnya, data peningkatan hasil belajar mata pelajaran prakarya dan kewirausahaan kelas X MIPA 1 SMA Negeri 4 Singaraja kecamatan buleleng kabupaten buleleng siklus I dan siklus II dapat dilihat pada Gambar. 2 dan Gambar 3.

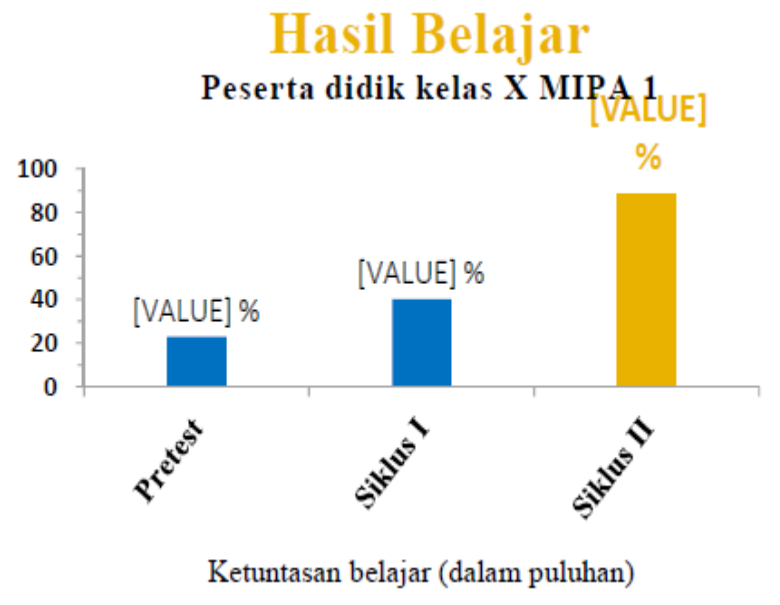

Gambar 2. Diagram batang hasil belajar peserta didik kelas X MIPA 1 


\section{Ketuntasan Belajar}

\section{Peserta Didik Kelas X MIPA 1}

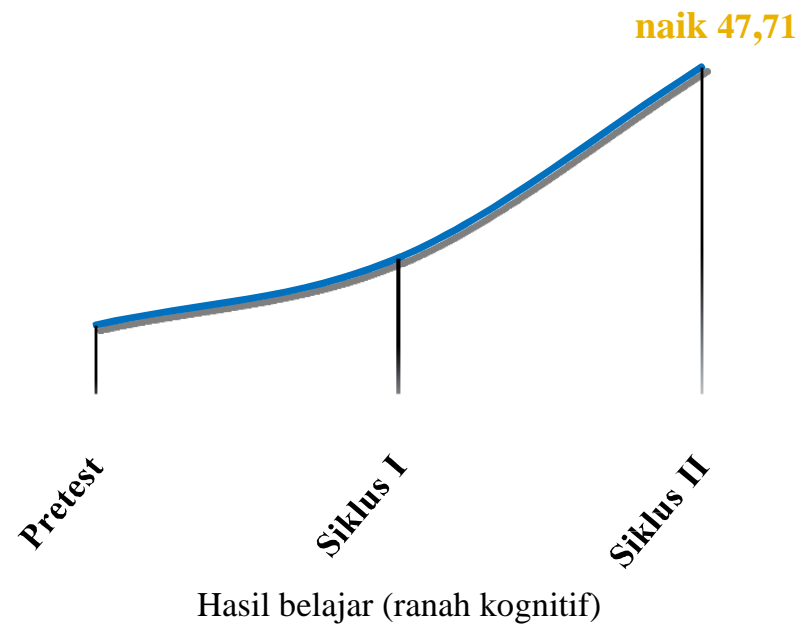

Gambar 3. Diagram garis ketuntasan belajar peserta didik kelas X MIPA 1

Berdasarkan hasil pemaparan tersebut, maka model pembelajaran problem based learning dapat meningkatkan hasil belajar prakarya dan kewirausahaan. Adapun berikut ini menjelaskan hal-hal yang menyebabkan meningkatnya, hasil belajar dan kelebihan pembelajaran berdasarkan masalah. Meningkatkan aktivitas belajar peserta didik kelas X MIPA 1 pada saat melaksanakan model pembelajaran problem based learning (PBL) yang dikategorikan tinggi pada siklus II, seperti yang disajikan pada tabel rekapitulasi hasil pengamatan dan Gambar. 4.

Tabel 6. Rekapitulasi hasil pengamatan aktivitas belajar siklus I dan siklus II

\begin{tabular}{llccc}
\hline & & Siklus I & Siklus II & \\
\hline 1 & & 3 & 4 & 5 \\
1 & Kegiatan Visual & 2,8 & 3,6 & Naik \\
2 & Kegiatan Oral & 3,2 & 3,4 & Naik \\
3 & Kegiatan Mental & 2 & 3,2 & Naik \\
4 & Kegiatan Emosional & 1,8 & 4 & Naik \\
\hline Jumlah & 9,8 & 14,2 & \\
Rata-rata (\%) & 61,25 & 88,75 & Meningkat \\
Kategori & Cukup & Sangat Baik & \\
Nilai maksimum & 16 & 16 & \\
\hline
\end{tabular}

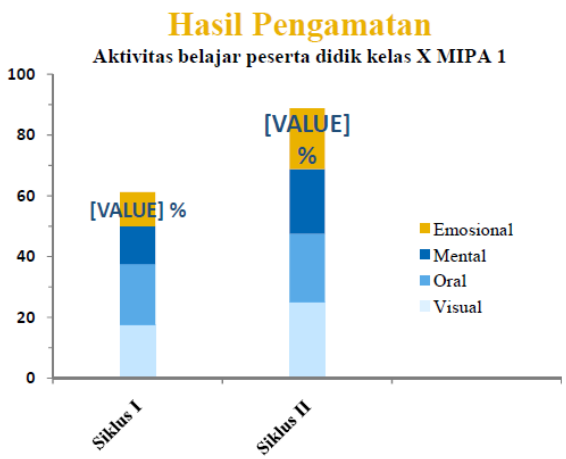

Gambar 4. Diagram batang bertingkat aktivitas belajar peserta didik kelas X MIPA 1 
Jika diperhatikan, pada sisi emosional (20\%) peserta didik yang belum memenuhi nilai maksimum (25\%) dibandingkan, dengan tiga kegiatan lainnya, seperti mental, oral, dan visual, yang menjadi aspek pengamatan pada aktivitas belajar peserta didik selama penelitian. Hal tersebut, yaitu "menyelesaikan kegiatan pengukuran dan tugas-tugas, dengan rasa tanggung jawab", karena dalam aktualisasinya, masih terdapat sebagian kecil dari peserta didik perannya, kurang aktif dalam kerja kelompok, yang merupakan tanggung jawabnya, seperti memberikan gagasan dan analisa pada data hasil pengukuran.

Banyak teori dan penelitian menegaskan kebutuhan bukan hanya akan sukses, tapi juga akan tantangan. Seperti yang dikutip oleh Paul Eggen "memberikan tantangan adalah salah satu ciri dari kegiatan yang secara intrinsik memotivasi" (Ryan \& Deci, 2000 dalam Paul Eggen dkk, 2012). Keberhasilan menunaikan tugas-tugas menantang memiliki setidaknya, tiga ciri yang memotivasi; 1) Mengembangkan persepsi tentang kompetensi. Setiap orang, termasuk peserta didik, ingin merasa "pintar", dan berhasil dalam tugas-tugas yang dipersepsikan sebagai menantang akan membantu peserta didik merasa pintar (Ryan \& Deci, 2000 dalam Paul Egen dkk, 2012), 2) Berkontribusi pada perasaan otonomi. Saat peserta didik berhasil di dalam tugastugas menantang, mereka merasa seolah-olah mengendalikan takdir mereka sendiri. (Baron, 1998 dalam Paul Egen dkk, 2012), 3) Menciptakan perasaan keseimbangan.

Orang berada di dalam kondisi keseimbangan saat mereka meyakini dunia itu aman dan bisa diramalkan serta masuk akal bagi mereka (Piaget, 1959 dalam Paul Egen dkk, 2012). Saat peserta didik berhasil dalam tugas-tugas menantang, mereka merasa seolah-olah dunia itu tertib dan bisa diramalkan.Tidak ada dari faktor-faktor ini beroperasi secara sama saat peserta didik berhasil dalam tugas-tugas remeh.

Keberhasilan yang dicapai oleh peserta didik di atas, tidak lepas dari dukungan. Kebutuhan akan keberhasilan di dalam motivasi belajar adalah nyata. Hanya seorang dewasa luar biasa yang mampu bertahan menghadapi kegagalan terus-menerus, dan ini bahkan lebih berlaku bagi peserta didik (Paul Eggen, 2012; hal 72). Sayangnya, tidak semua peserta didik berhasil, namun untuk meningkatkan peluang sukses bagi sebagian besar peserta didik terdapat sejumlah cara; 1) Memulai pelajaran, dengan pertanyaan terbuka. Pertanyaan-pertanyaan seperti "Apa yang kalian amati?" dan "Bagaimana kita membandingkan ini?" memungkinkan beragam respons berterima dan mengundang keberhasilan, 2) Mengembangkan pelajaran, dengan bertanya dan menyemangati peserta didik saat mereka mengalami kesulitan menjawab, 3) Memberikan praktik dan latihan, dengan dukungan guru sebelum meminta peserta didik bekerja sendiri.Menilai secara menyeluruh dan sering serta memberikan umpan balik mendetail tentang kemajuan belajar.

Kegiatan-kegiatan lapangan adalah cara lain untuk mendorong keterlibatan dan minat peserta didik (Zahorik, 1996 dalam Paul Eggen dkk, 2012). Misalnya pada penelitian ini, saat peserta didik bergulat pada proses pengukuran arus listrik dan menghitung biaya pemakaian listrik, dan menganalisis masalah yang ada pada rangkaian amplifier.Menyebabkan tingkat minat mereka meningkat secara signifikan. Dilihat dari kegiatan mental dan emosional.

\section{Simpulan dan Saran}

Dari rangkuman hasil penelitian yang dijabarkan di atas, dapat diketahui bahwa model pembelajaran problem based learning dapat meningkatkan hasil belajar (ranah kognitif) mata pelajaran prakarya dan kewirausahaan pada materi konsep alat komunikasi. Mengacu pada hasil penelitian, dengan sempel peserta didik kelas X MIPA 1 sebanyak 35 orang di SMA N 4 Singaraja. Mendapatkan nilai tes hasil belajar peserta didik mengalami peningkatan yang cukup signifikan dalam dua siklus tindakan. Dan berimbas peningkatan ketuntasan belajar peserta didik yang pada akhirnya, mencapai $88,57 \%$ yang dikategorikan "tuntas", maka hasil tersebut sudah memenuhi indikator keberhasilan tindakan yang ditetapkan pada penelitian ini, yaitu memenuhi kriteria ketuntasan minimal $\geq 75$ dan secara klasikal ketuntasan belajar telah melebihi $75 \%$.

Dari pembahasan di atas maka, hal yang dapat disarankan adalah sebagai berikut: 1) Model pembelajaran problem based learning (PBL) meningkatkan aktivitas peserta didik dalam mengikuti pembelajaran dan pemahaman terhadap materi. Maka guru dapat menjadikan model ini, sebagai alternatif dalam menetukan strategi mengajar untuk menanggulangi redahnya, 
kualitas pembelajaran, 2) Guru dapat melatih dan mengembangkan kemampuan berpikir peserta didik dan menjadikannya, pembelajar yang otonom. Dari penerapan model problem based learning (PBL) yang nantinya, sebagai strategi mengajar, 3) Indikator keberhasilan penelitian yang sudah tercapai, yaitu secara klasikal rata-rata ketuntasan belajar telah melebihi

$75 \%$. Namun, hasil yang telah dicapai dalam penelitian ini, yaitu 88,75\% tentu dapat dimaksimalkan lagi, dengan dukungan dari segala pihak. Sehingga nantinya, juga akan menambah objektivitas dari hasil penelitian.

\section{Daftar Pustaka}

Aminudin. 1990. Pengembangan Penelitian Kualitatif dalam Bidang Bahasa dan Sastra. Malang: Yayasan Asah Asih Aspuh.

Basuki, Sulistyo. 2006. Metode Penelitian. Jakarta: Wedatama Widya Sastra.

Bilgin, I., E. Senocak, dan M. Sozbilir. 2008. The Effects Of Problem-Based Learning Instruction On University Students' Performance Of Conceptual And Quantitative Problems In Gas Concepts. Eurasia Journal Of Mathematics, Science \& Technology Education, 5(2), 153164.

Ibrahim, Muslimin dkk. 2000. Pembelajaran Berdasarkan Masalah. Surabaya: Universitas Negeri Surabaya.

Kartono, Kartini. 1996. Psikologi Umum. Bandung: CV. Mandar Maju.

Kemmis, S dan Mc. Taggart. 2000. The Action Research Planner Third Edition. Victoria: Deakin University Press.

Liang, Gie The. 1982. Dari Administrasi ke Filsafat. Yogjakarta : Supersukses. Paul, Eggen (dkk). 2012. Strategi dan Model Pembelajaran. Jakarta: Indeks.

Pendit, Putu Laxman. 2003. Penelitian Ilmu Perpustakaan dan Informasi: Sebuah Pengantar Diskusi Epistomologi dan Metodologi. Jakarta: Fakultas Sastra Universitas Indonesia.

Permendiknas. 2009. Undang-Undang SISDIKNAS No. 20 Th. 2003. Jakarta: Sinar Grafika Purwanto, Ngalim. 2004. Prinsip-prinsip dan Teknik Evaluasi Pengajaran. Bandung: Remaja Rosda Karya.

Rahmat, Kusumawardhani. 2016. Pengaruh Problem Based Learning (PBL) Dengan Strategi Team-Assisted Individualization (TAl) Terhadap Kemampuan Pemecahan Masalah Siswa SMP N 1 Susukan. Purwokerto.

Salam, Burhanuddin. 1997. Logika Materiil Filsafat IImu Pengetahuan. Jakarta: Rineka Cipta. Sutopo, Ariesto Hadi. 2002. Animasi dengan Macromedia Flash berikut Action Script. Jakarta: Salemba infotek.

Sugiyono. 2010. Metode Penelitian Pendidikan. Bandung: Alfabeta.

Sudjana, Nana. 2009. Dasar-Dasar Proses Mengajar. Bandung: Sinar Baru Algensindo Offset. Tan, O.S. 2003. Problem-Based Learning Innovation: Using problems to power learning in the $21^{\text {st }}$ century. Singapore: Thomson Learning.

Yuli Eko Siswono, Tatag. 2010. Pembelajaran Matematika Berbasis Pengajuan dan Pemecahan Masalah (JUCAMA) Untuk Meningkatkan Kemampuan Berpikir Kreatif Siswa. Makalah Seminar: Surabaya 